which Dr. E. C. Watson describes the prominent members of the Paris Academy of Sciences in its early days. This article is based on engravings by Sébastien Le Clerc, a number of which are reproduced. In 1670, Le Clerc was engaged by Colbert as Court engraver and in this capacity he contributed illustrations to several notable works produced by the Academy with the direct encouragement of the king. To this circumstance is due a pictorial representation of the membership and apparatus of the Academy in several settings. This pleasant account makes it a matter for regret that no contemporary artist gave similar attention to the Royal Society.

The volume closes with a short article by Sister M. E. Keenan on "St. Augustine and Biological Science". Perhaps natural history would be more appropriate, and indeed the subject is rather literary than scientific. The source of Augustine's allusions is clearly Virgil and Pliny rather than Nature, and though he may have treated current lore with some reserve, his powers of observation do not seem to have been more than moderate.

H. C. Plummer.

\title{
SCIENCE IN BREWING
}

\section{Brewing}

Science and Practice. By H. Lloyd Hind. Vol. 2 : Brewing Processes. Pp. xiv $+507-1020+62$ plates. (London : Chapman and Hall, Ltd., 1940.) $56 s$. net.

I $\mathrm{T}$ may be said, at some risk of repetition, that brewing is an art, developed throughout the centuries without aid from science. Science now steps in to explain what happens in the brewery, why certain procedures give good and others bad results. Research, both fundamental and technical, is increasing every year the value of science, now harnessed to the art of the brewer.

An example of this function of science in the brewery may be cited. The importance of aeration in securing a satisfactory brewery fermentation has been realized since Pasteur's time. In more recent times the purely mechanical function of aeration, that of 'rousing' or mixing the yeast back into the fermenting wort until it has finished the fermentation, has been stressed. Also within recent years the relationships between alcoholic fermentation, respiration and yeast growth have become much clearer. It now emerges that, fundamentally, aeration in the brewery fermentation vessel is merely necessary to secure healthy growth of the yeast from the small amount that the brewer seeds to the wort to the much larger amount that he normally removes from it. There is no scientific reason why a much higher yeast seed-rate should not be used in practice. This would result in a swifter fermentation and little time for multiplication. Aeration would be quite unnecessary in such a case. The fact is that beer is not, and never was, made in this way, and probably it would have a yeasty flavour and other different characters if it were so made. Moreover, the problem of a supply of healthy seed yeast would arise. But the apparent contradiction between theory (as propounded by Pasteur) and practice in breweries is explained. Science explains the brewers' empiricisms.

Such is one function of the excellent work under notice. To the technician in the brewing industry, it is of course, much more than a mere explanation of long-established practice. It is with its com. panion volumes a complete handbook of the brewer's art and craft.

The materials used in brewing had been exhaustively treated in vol. 1, which appeared about two years ago. The present volume deals with plant and processes, except that the whole of the processes involved in the bottling of beer are postponed for treatment in a third volume to appear later.

The chapters dealing with mashing are very good. Here, as elsewhere, the opportunity has been taken to incorporate into this volume recent scientific advances which have been published since the previous volume was written. There is also shown throughout a satisfactory blend of scientific diseussion and practical empiricism. The processes of boiling with hops, cooling (involving flocculation of protein-tannin compounds), fermentation, conditioning of draught beer, and sections on relevant micro-organisms follow. An admirable chapter on bacteriology as it affects the brewer is contributed by Dr. J. L. Shimwell.

A large number of excellently reproduced photographs of brewery plant adorn the volume, whilst the photomicrographs of yeast in ultra-violet light are the best the reviewer has ever seen. A summary and list of references appear at the end of each chapter, whilst author and subject indexes terminate the volume. The author's long experience as brewer and chemist, supplemented by extensive reading and painstaking labour, have resulted in a book which should be of inestimable value to technicians engaged in the trade. 